\title{
Social Support of Toba-Bataknese Mothers in Children's Education
}

\author{
Rahma Fauzia, Meutia Nauly, Ridhoi Meilona Purba
}

\author{
Department of Clinical Psychology \\ Faculty of Psychology \\ University of Sumatera Utara, Medan, Indonesia \\ rahma.fauzia@usu.ac.id, tianauly@gmail.com,ridhoi.purba@gmail.com
}

\begin{abstract}
Toba-Bataknese women known as hard workers, have a major contribution towards their children's education. As Toba-Bataknese people who have three goals of life as cultural mission which are hagabeon (blessed by heredity), hamoraon (wealth), and hasangapon (honor), they believed education is the only way to reach "the glory of life". Their child who has a good education is the most precious treasure (anakkokin do hamoraon di ahu). This study try to reveal the social support of Toba-Bataknese mothers in order to make sure their children to have the good education. TobaBataknese mothers $(\mathrm{N}=136)$ in Medan filled out questionnaire with open-ended questions developed from social support theory by Sarafino. There are four types social support: emotional/esteem support, tangible/instrumental support, informational support, and companionship support. This study used the quantitative method, all the responses were categorized and then analyzed by using croos tabulation statistical methods. The result showed that most of TobaBataknese mothers were having difficulty in providing school's funding, especially in low income family with more than one child. The most social support received is tangible/instrumental support from the Toba-Bataknese mother's clan (female line). This finding is interesting knowing the Toba-Bataknese has patrilineal kinship system that so dominant that can be traced through the male line. The informational support received in form of some advices, and the companionship support received in form of helping them to taking care of their children. This study didn't showed any of emotional/esteem support received by Toba-Bataknese mothers.
\end{abstract}

Keywords—-social support; Toba-Bataknese mothers; children's education

\section{INTRODUCTION}

In general, women are more often oriented towards the domestic realm, although in the progress of women is also expected to be in the public domain due to various reasons. Economic conditions is one strong reason for women to be in the public realm, eventhough the roles within the public are often considered an extension of the domestic under appreciated role in many society. Various studies have revealed the existence of a patriarchal culture that believes men are superior and women inferior that used to justify men to dominate and control women. This is in line with Walby (1990) that defines patriarchy as a system of social structures and practices in which men dominate, oppress and exploit women.

The Toba-Bataknese has patrilineal kinship system that so dominant that can be traced through the male line. Men as the main actor control various areas in life, including in marital life, law, inheritance, and land ownership; while women seems to be living at the hands of men. On the other side, there happen to be a paradox since the Toba-Bataknese women known as hard workers in meeting the household life, they do whatever necessary either as farmers, cultivators and small traders (parengge-rengge), or as informal traders inang-inang). Toba-Bataknese women have a significant role for the family survival and contribute fairly prominent for their children's education (Baiduri, 2014).

As Toba-Batak people who have three goals of life as cultural mission which are hagabeon (blessed by heredity), hamoraon (wealth), and hasangapon (honor), they believed education is the only way to reach "the glory of life". Their child who has a good education is the most precious treasure (anakkokin do hamoraon di $a h u$ ). The implication they will work the hardest they can to send their children to school (Harahap and Hotman, 1987; Irmawati, 2007; Napitupulu, 2011; Baiduri, 2014) 
In order to make sure their children to have a good education, the Toba-Bataknese mothers, like any mothers, would face many problems and need supports from their family or community. Supports from others could be stated as social support, as social support defined as the action of help from others to the person in times of need. There are four types of social support: (1) emotional or esteem support that provides comfort and reassurance with a sense ofbelongingness and of being loved in times of stress, itincludes sense of empathy, caring, concern,positive regard, and encouragement toward the person; (2) tangible or instrumental support in form of direct assistance; (3) informational support in form of suggestion, feedback, and advice; and (4) companionship support by giving a feeling of membership in group such as spending time with the person (Sarafino, 2011).

Therefore, this study try to reveal the social support of Toba-Bataknese mothers received to help them to overcome problems in their children's education.

\section{MATERIALS AND METHODS}

\section{A. Participants}

Participants in this study included 145 TobaBataknese mothers live in Medan, but nine of them were excluded because of not completed the whole questions.

The total income per month of the participants is ranging from under $\mathrm{Rp} 2.000 .000$ to $\mathrm{Rp}$ 20.000.000: 37\% under Rp 2.000.000 per month, $44 \%$ Rp 2.000.000 - Rp 4.000.000 per month, 30\% Rp 4.000.000 - Rp 6.000.000 per month, 21\% Rp 6.000.000 - Rp 10.000.000 per month, and 4\% Rp 10.000.000 - Rp 20.000.000 per month.

The number of children they have ranging between one to five children: $29 \%$ having one child, $45 \%$ having two children, $20 \%$ having three children, $18 \%$ having four children, and $24 \%$ having five children.

\section{B. Questionnaire}

The questionnaire in this study developed from social support theory by Sarafino (2011) in form of six open-ended questions. All of the participants' responses to open-ended questions were typed into master list, and then all the responses were categorized into several theme.

\section{Data Analysis}

Based on the themes that emerged in categorization, statistical analysis using cross tabulation were performed in this study.

\section{RESULT AND DISCUSSION}

\section{A. Main Problem in Children's Education}

The result shows that most of Toba-Bataknese mothers were having difficulty in providing school's funding (67.65\%), especially in low income family with more than one child.

Other problems related with difficulty managing time between working and taking care of the children, facing the children that have low motivation to go to school because their teachers gave them lots of school assignment.

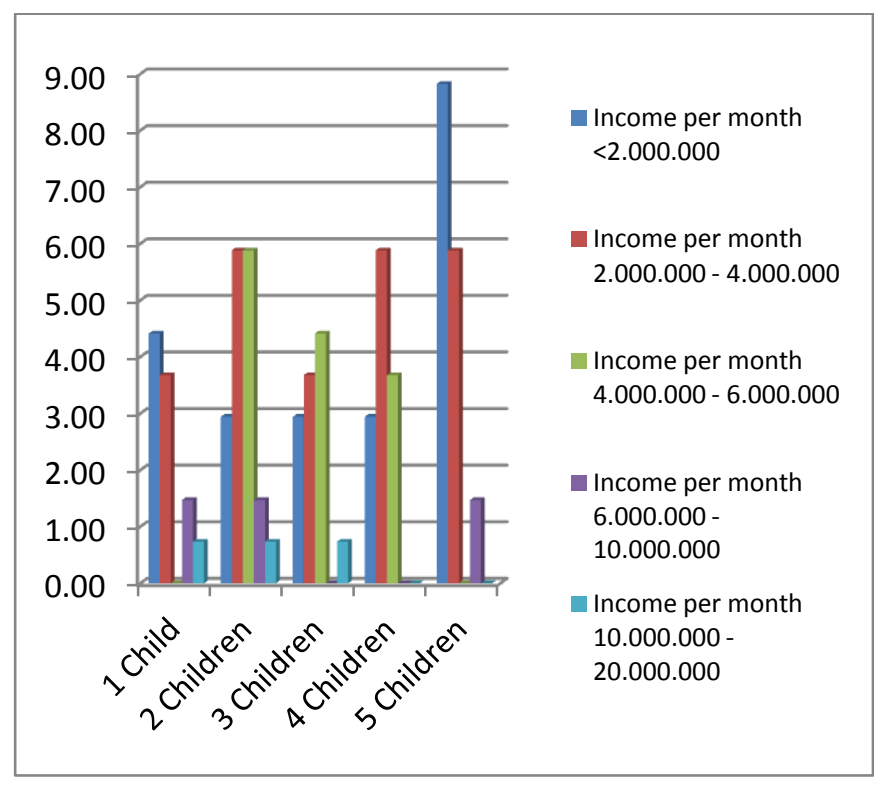

Fig. 1. Difficulty in school's funding

\section{B. Social Support of Toba-Bataknese Mothers}

The most social support received by TobaBataknese mothers is instrumental support in form of money, jobs, and school supplies (71.3\%). The informational support received in form of some advices and sharing experiences (27.2\%), and the companionship support received in form of helping them to taking care of their children (8.1\%).

The interesting finding is this study find $0 \%$ of emotional support received by Toba-Bataknese 
mothers. According to the anthropologist, Pelly (personal communication, 2016), Toba-Bataknese people internalized sense of competitiveness since childhood, they have the desire "to be number one" in everything they do. The implication of this sense of competitiveness was they have to dissemble their affection side, hoping they could push their weakness to the lower level in order to be the number one. They always have what Pelly called "creedo" ("cry the heart out"), because if they failed in one aspect of life they would get mocked by the society, even by their own family. It's not appropriate to show the weakness. If they failed in doing something, then they have to try even harder to accomplish it. Therefore they see problems in their life as something which must be passed, it's forbidden to break down and cry over it.

That is why Toba-Bataknese people didn't good in expressing their feeling to others, not because they didn't have empathy toward others, but simply because they were trained to believe that if they showed empathy toward others, it would make other getting more weak to overcome the problems. However, we do need future research to confirm this explanation.

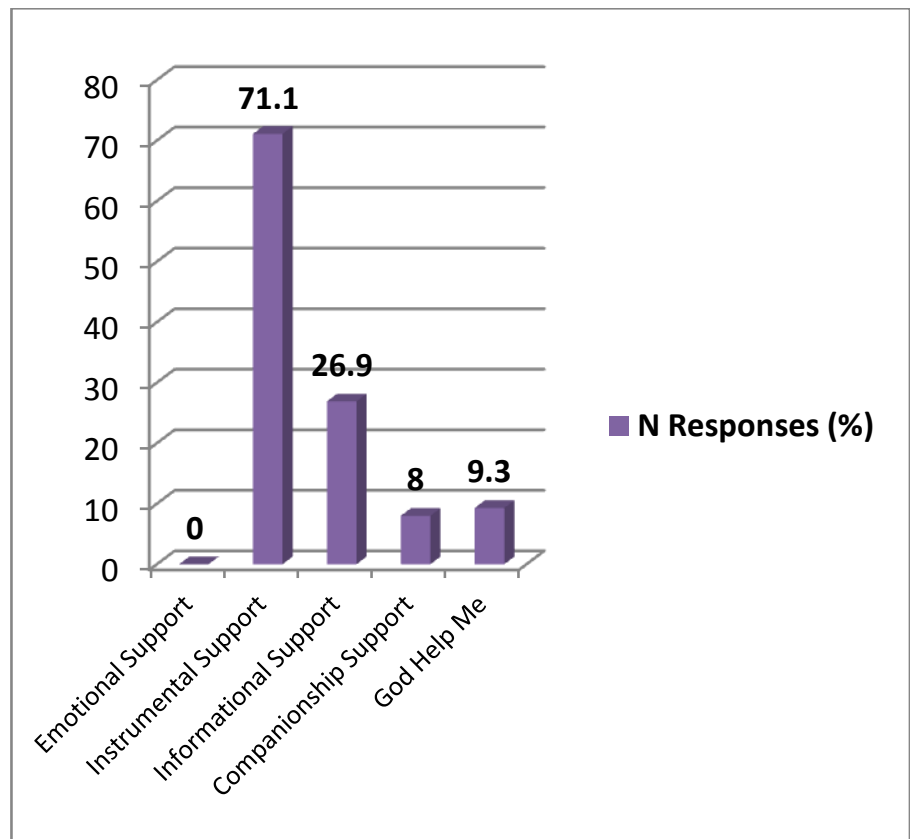

Fig. 2. Social support of Toba-Bataknese mothers

\section{Source of Social Support}

This study reveal that most social support received is from the female line, which is the TobaBatak mothers's clan (65.4\%), while the social support received from the male line only $14 \%$. This finding is interesting knowing the Toba-Bataknese has patrilineal kinship system that so dominant that can be traced through the male line. Pelly point out that in Toba-Bataknese, since childhood the female line became the assistance parties when they were facing problems. The mother's clan is seen as the "comfort place" when life become unbearable. Instead of "running" to the father's clan who would mocked them, they "run" to the mother's clan (personal communication, 2016).

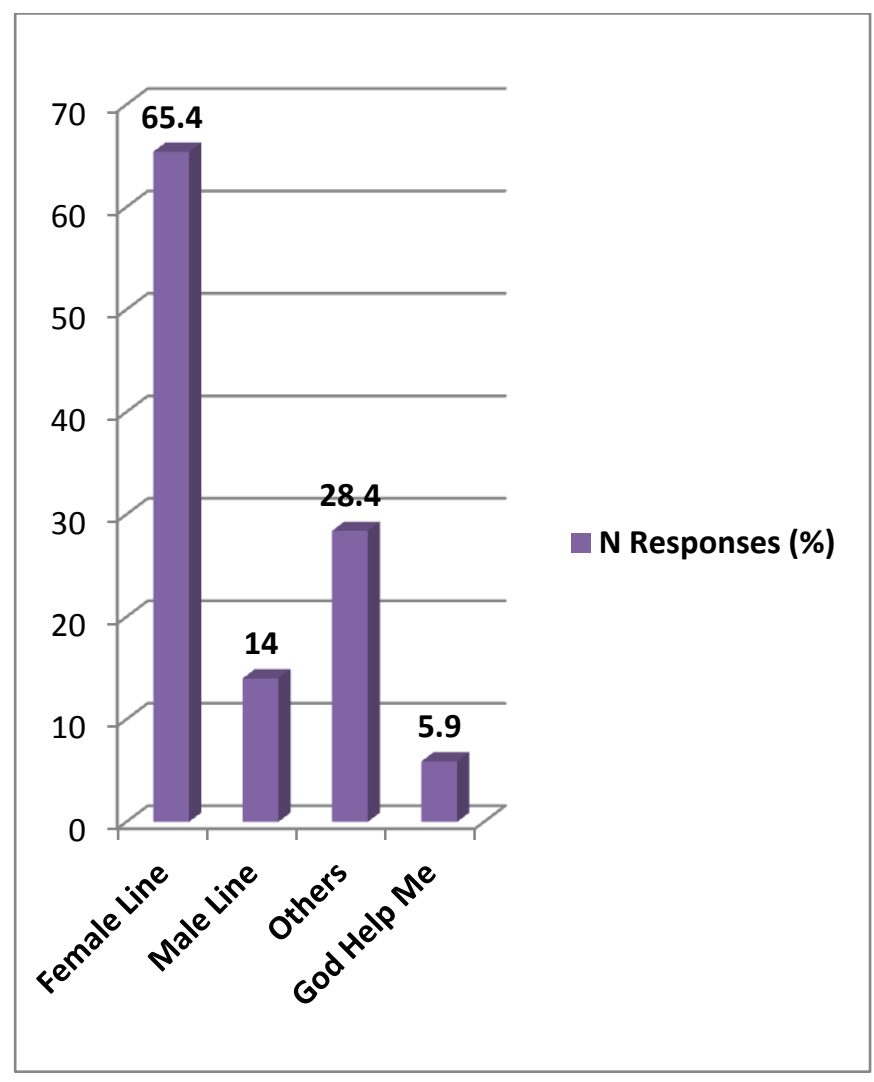

Fig. 3. The significanct assistance

This study also reveal the Toba-Bataknese mothers receive the social support from people outside their family (28.4\%). According to Pelly, the Toba-Bataknese worship the friendship they have (rajani dongan), they would do everything to help their friends (personal communication, 2016). 
Another interesting finding in this study is the Toba-Bataknese mothers seek help from God (5.9\%). They believed God will give them what they need to solve their problems. Christianity is the majority religion of Toba-Batak people, there is synergistically relation between cultural values and religion in TobaBataknese people. However, future research is needed to reveal this finding.

\section{CONCLUSION}

The result of this study cannot be generalized to all of Toba-Bataknese mothers, we need more future researches to elaborate this study by increasing the number of samples. We also suggest for the future research to conduct a comparative study between Toba-Bataknese mothers in rural and urban areas to have the bigger picture about TobaBataknese mothers in children's education.

This study found two interesting findings that needed to be explored through future researches. First,this study didn't showed any of emotional/ esteem support received by Toba-Bataknese mothers. We questioning this finding whether this is because the character of Toba-Bataknese people or there are other reasons. Therefore, we need to do future research to confirm the explanation. Second, we found that the significant assistance are from their mother's clan (female line) and their friends, but we can not yet make a solid conclusion about the role of the father's clan (male line) in children's education. The finding is very interesting knowing the Toba-Batak has patrilineal kinship system that so dominant that can be traced through the male line. We sugest for the future researchers to study the role of Toba-Bataknese fathers (male line) in children's education.

\section{ACKNOWLEDGEMENT}

Authors would like to thank University of Sumatera Utara for giving us a chance to conduct a research through TALENTA funding. We would also like to show our gratitude to Professor Usman Pelly,
Ph.D and Dr. Ratih Baiduri, M.Si for sharing their pearls of wisdom about Toba-Bataknese culture with us during the course of this research.

\section{REFERENCES}

Baiduri, R. (2014). The Meaning And Dimensions of Work: Women Traders Toba-Batak (InangInang) in Medan, North Sumatera, Indonesia. International Journal of Humanities and Social Science, vol. 4 (1), pp. 66-74.

Harahap, B., Hotman, M. S. 1987. Orientasi Nilainilai Budaya Batak Suatu Pendekatan Terhadap Prilaku Toba-Batak Angkola-Mandailing. Jakarta: Sanggar Willem Iskandar.

Irmawati. (2007). Nilai-nilai yang Mendasari Motif-motif Penentu Keberhasilan Suku Batak Toba (Studi Psikologi Ulayat). Dissertation. Program Pascasarjana Fakultas Psikologi Universitas Indonesia.

Napitupulu,V. M. (2011). Pendidikan sebagai Faktor Dinamisasi dan Integrasi Sosial dalam Masyarakat Tapanuli Utara: Pemikiran tentang Batak Setelah 150 Tahun Agama Kristen di Sumatera Utara. Jakarta: yayasan Pustaka Obor Indonesia.

Sarafino, E. P., Smith, T. W. (2011). Health Psychology: Biopsychosocial Interaction ( $7^{\text {th }}$ ed). USA: John Wiley \& Sons, Inc.

Walby, S. (1990). Theorizing Patriarchy. Oxford: Blackwell. 